\title{
STUDI KOMPARASI HASIL BELAJAR MODEL PEMBELAJARAN SCRAMBEL DAN MODEL NUMBERED HEAD TOGETHER NHT PADA MAHASISWA PGSD UNIPA SURABAYA
}

\author{
Danang Prastyo \\ Pendidikan Guru Sekolah Dasar Universitas PGRI Adi Buana Surabaya \\ danang_pgsd@yahoo.com
}

\begin{abstract}
Tujuan peneltian ini mengetahui perbedaan hasil belajar model pembelajaran Scrambel dan model pembelajaran NHT pada mahasiswa PGSD Unipa. Populasi penelitian ini mahasiswa PGSD Unipa Surabaya angkatan 2016. Sedangkan sampel penelitian ini adalah mahasiswa angkatan 2016 kelas A, B dan C. Penelitian ini menggunakan penelitian eskperimen. Desain penelitian menggunakan Randomized Control Group Pretest-Postest Desaing. Sedangkan untuk teknik analisis data dilakukan dengan bantuan program statistik SPSS versi 16. Dari hasil analisis spps menunjukkan ada perbedaan hasil belajar antara model pembelajaran $S$ crambel dengan model pembelajaran NHT sebesar $0.000<1 / 2 \alpha(0,005)$. Sehingga penerapan model pembelajaran Scrambel dan NHT berpengaruh terhadap hasil belajar.
\end{abstract}

Kata Kunci: Model Scrambel, Model NHT, Hasil Belajar.

Abstract

The purpose of this study is to find out the differences in learning outcomes of the Scrambel learning model and the NHT learning model for students of PGSD Unipa. The population of this study was the 2016 class of PGSD Unipa Surabaya. While the sample of this study were students of class 2016, class A, B and C. This study uses experimental research. The research design used the Randomized Control Group Pretest-Postest Desaing. Whereas for data analysis techniques were carried out with the help of the SPSS version 16 statistical program. From the results of the spps analysis, there are differences in learning outcomes between the Scrambel learning model and the NHT learning model of $0.000<1 / 2 \alpha(0.005)$. So that the application of the Scrambel and NHT learning models affect learning outcomes.

Keywords: Scrambelled Model, NHT Model, Learning Outcomes

\section{PENDAHULUAN}

Berkembangnya model - model pembelajaran menuntut pendidik untuk dapat menerapkan model pembelajaran yang efektif dan efesien. Dari banyaknya model pembelajaran, tidak semuanya memberikan kontribusi besar bagi perkembangan peserta didik. Sebagai pendidik diharapkan dosen dapat memilih model pembelajaran yang tepat, karena dengan pengaplikasian model pembelajaran yang tepat akan berpengaruh besar terhadap meningkatnya hasil belajar peserta didik.

Jika dilihat realitanya, masih terlihat sebagian pendidik ketika mengajar masih menerapkan model pembelajaran konvensional atau berfokus pada teacher center. Padahal jika dilihat pengaplikasian model pembelajaran konvensional dapat memberikan dampak negatif bagi perkembangan berfikir dan kreativitas peserta didik. Model pembelajaran konvesional lebih berfokus pada pendidik yang mengajar tanpa memberikan kesempatan dan ruang bagi peserta didik untuk belajar dan aktif dalam mengikuti setiap kegiatan dalam pembelajaran. Jika cara pembelajaran konvensional tidak dirubah maka menjadi penghambat bagi peserta didik untuk bisa menjadi pribadi atau lulusan yang memiliki daya berfikir dan kreatif dalam menyelesaikan masalahnya. 
Sebagai pendidik di pendidikan tinggi, penerapan model pembelajaran koperatif dinilai mampu meningkatan hasil belajar mahasiswanya. Muslimin (2000:16) mengatakan, dari hasil penelitian menunjukkan hasil bahwa penerapan pembelajaran koperatif terbukti lebih unggul dalam mengoptimalkan hasil belajar peserta didik jika dibandingkan dengan pengalamanpengalaman belajar individual. Isjoni (2007:6) mengatakan pembelajaran koperatif merupakan sebuah aktivitas dalam mengajarkan sesuatu secara bersama dengan saling bekerjasama satu dengan lainnya sebagai satu kelompok. Nur dan Wikandari, (2004:25) mengatakan, model pembelajaran koperatif merupakan sebuah model pembelajaran yang dilakukan peserta didik secara bersama-sama dalam kelompok kecil dengan cara bekerjasama).

Menurut Shoimin (2014: 166), model pembelajaran Scramble merupakan sebuah pembelajaran yang merangsang peserta didik untuk mencari dan menemukan jawaban serta menyelesaikan permasalahan yang ada. Tailor (dalam Huda 2013: 303) mengatakan model pembelajaran Scramble merupakan sebuah metode pembelajaran yang mampu meningkatkan kecepatan dan konsentrasi berpikir peserta didik. Sedangkan Menurut Muslimin (2005:28) ada beberapa langkah yang harus dirapkan pendidik dalam mengplikasikan model pembelajaran NHT yaitu: Numbering (penomoran). Questioning (mengajukan pertanyaan). Heads together (berfikir bersama). Answering (menjawab). Melihat kelebihan model pembelajaran Scramble dan NHT peneliti ingin melakukan penelitian terkait dengan perbedaan hasil belajar kedua model tersebut. Untuk itu judul penelitian ini adalah Adakah Perbedaann Hasil Belajar Model Pembelajaran Scrambel dan Model Pembelajaran NHT Pada Mahasiswa PGSD Unipa Surabaya.

\section{KAJIAN LITERATUR DAN PEGEMBANGAN HIPOTESIS}

Shoimin (2014: 166) mengaakan, model pembelajaran scramble merupakan sebuah pembelajaran yang merangsangi peserta didik untuk mencari dan menemukan jawaban. Sementara itu menurut Slavin (dalam Huda 2013: 203) model pembelajaran NHT merupakan pengembangan dari diskusi kelompok dan model tersebut sesuai untuk memastikan akuntabilitas individu dan diskusi kelompok.

Dalam pelasanaanya masing-masing model pembelajaran tersebut sama-sama memiliki, hal ini terlihat dari hasil penelitian sebagai berikut yaitu Fitriyah N (2017) menyatakan penerapan metode pembelajaran Scramble dapat menaikkan prestasi belajar peserta didik pada mata pelajaran IPS, ini terlihat dari aktivitas guru mengalami peningkatan pada siklus I $65,3 \%$, siklus II $75,9 \%$, sedangkan pada siklus III meningkat menjadi 90,3\%. Aktivitas peserta didik dari siklus I $66,25 \%$, siklus II $76,25 \%$, dan pada siklus III meningkat menjadi 90\%. Hasil belajar siswa meningkat dari siklus I $46 \%$, siklus II $75 \%$, dan pada siklus III menjadi $89 \%$.

Sya'ban Veni (2016) menyatakan pada kelompok yang menerapkan metode scramble memiliki minat lebih tinggi belajar IPS lebih daripada kelompok dengan menggunakan metode ceramah pada siswa kelas V SD Negeri Rejowinangun 1 Yogyakarta tahun ajaran 2015/2016. Ini terlihat dari tingginya skor pada minat belajar IPS pada kelas eksperimen sebesar 79,36 dan skor kelas kontrol sebesar 75,83.

Umar (2016) menyatakan, model pembelajaran STAD terbukti mampu menaikkan hasil belajar peserta didik pada materi uang dan lembaga keuangan bukan bank. Iini terlihat dari daya serap kelas klasikal pada pembelajaran pada siklus I sebesar $48,7 \%$ sedangkan siklus II sebesar $94,8 \%$.

Septiaingrum, Resti dkk (2014) menyatakan, penerapan model NHT dapat menaikkan kemampuan memori dan hasili belajar pada sistem koloid peserta didik XI IPA 2 SMA Negeri 2 Karanganyar. Ini terlihat dari meningkatnya kemampuan memori pada siklus I sebesar $41,67 \%$ dan siklus II sebesar 69,44\%.

\section{METODE PENELITIAN}

\section{Rancangan Penelitian}

Penelitian ini peneliti menggunakan penelitian eksperimen. Penelitian eksperimen akan dilakukan pada tiga kelas, yaitu satu kelas dengan model Scrembel, satu kelas 
WAHANA

Volume 70, Nomor 2, 1 Desember 2018

dengan model NHT dan satu kelas konvensional sebagai kontrol.

\section{Sampel Pene litian}

Uji coba dilaksanakan pada Jurusan PGSD Unipa tahun 2016 dengan memilih satu kelas secara acak dari tiga kelas paralel yang berkemampuan setara.

ditempatkan secara acak dan adanya pretest dan posttes untuk memastikan efektiviatas perlakuan yang diberikan. Rancangan Eks perimen

\section{Keterangan :}

$\mathrm{X} 1$ = Perlakuan model Scrambel

$\mathrm{X} 2$ = Perlakuan model NHT

$\mathrm{X}=$ Konvensional

T1 = Pretest kelompok Eksperimen 1,2 dan kelompok kontrol

$\mathrm{T} 2=$ Post-test kelompok Eksperimen 1,2 dan kelompok kontrol.

\section{HASIL DAN PEMBAHASAN}

Dari hasil analisis SPSS menunjukkan adanya perbedaan hasil belajar pada model pembelajaran Scrambel dan NHT, hal ini dapat dilihat dari nilai Asymp. Sig. (2tailed) pada model pembelajaran Scrambel dan nilai Asymp. Sig. (2-tailed) pada model pembelajaran NHT. Analisis data pada penelitian ini menggunakan Uji Mann Whitney, dimana data yang
e-ISSN : $2654-4954$, p-ISSN : $0853-4403$

\section{Rancangan Penelitian}

Penelitian ini menggunakan desain Randomized Control Group Pretest-Postest Desaing. Maksum (2009: 49) mengatakan, desain ini dinilai mendekati sempurna karena ada kelompok kontrol, ada perlakukan, subjek

\begin{tabular}{||c|c|c|c||}
\hline \hline Kelompok & $\begin{array}{c}\text { Pre } \\
\text { tes }\end{array}$ & $\begin{array}{c}\text { Perla } \\
\text { kuan }\end{array}$ & $\begin{array}{c}\text { Pos } \\
\text { test }\end{array}$ \\
\hline Eksperimen 1 & $\mathrm{T} 1$ & $\mathrm{X} 1$ & $\mathrm{~T} 2$ \\
Eksperimen 2 & $\mathrm{T} 1$ & $\mathrm{X} 2$ & $\mathrm{~T} 2$ \\
Kontrol & $\mathrm{T} 1$ & $\mathrm{X}$ & $\mathrm{T} 2$ \\
\hline
\end{tabular}

\section{Teknik Analisis Data Eksperimen}

Pada penelitian ini digunakan dua teknik analisis data, yaitu analisis statistik deskriptif dan analisis statistik inferensial. Sementara itu untuk menguji hipotesis dengan menggunakan program SPSS versi 16.0 for windows.

diperoleh tidak berdistribusi normal. Sedangkan untuk rata-rata hasil belajar tertinggi diduduki model pembelajaran NHT dengan nilai sebesar 75.50, kedua model pembelajaran konvensional 71.75 dan ketiga model pembelajaran Scrambel 69,58. Untuk hasil analisis datanya dapat dilihat pada tabel berikut ini:

\begin{tabular}{|ll|r|r|}
\multicolumn{3}{|c|}{ Descriptives } \\
\hline \multicolumn{2}{|c|}{ Statistic } & Std. Error \\
\hline Posttest & Mean & 75.5000 & .98042 \\
NHT & 95\% Confidence Interval for Lower Bound & 73.5053 & \\
& Mean & 77.4947 & \\
& Upper Bound & 75.6634 & \\
5\% Trimmed Mean & 75.5000 & \\
Median & 32.682 & \\
Variance & 5.71680 & \\
Std. Deviation & 60.00 & \\
Minimum & 86.00 & \\
Maximum & 26.00 & \\
Range & 5.00 & \\
Interquartile Range & -.356 & .403 \\
Skewness & .897 & .788 \\
\hline
\end{tabular}


Volume 70, Nomor 2, 1 Desember 2018

\section{Descriptives}

\begin{tabular}{|lll|r|r|}
\hline & & Statistic & Std. Error \\
\hline Posttest & Mean & 71.7576 & 1.24623 \\
Konvesional & 95\% Confidence & Lower Bound & 69.2191 & \\
& Interval for Mean & Upper Bound & 74.2961 & \\
& 5\% Trimmed Mean & & 71.8973 & \\
Median & 73.0000 & \\
Variance & 51.252 & \\
Std. Deviation & 7.15904 & \\
Minimum & 60.00 & \\
Maximum & 81.00 & \\
Range & 21.00 & \\
Interquartile Range & 12.00 & \\
Skewness & -.563 & .409 \\
Kurtosis & -.975 & .798 \\
\hline
\end{tabular}

\section{Descriptives}

\begin{tabular}{|c|c|c|c|}
\hline & & Statistic & Std. Error \\
\hline \multirow{13}{*}{$\begin{array}{l}\text { Posttest } \\
\text { Scrambel }\end{array}$} & Mean & 69.5882 & \multirow[t]{6}{*}{1.19500} \\
\hline & \multirow{2}{*}{$\begin{array}{l}\text { 95\% Confidence Interval for } \\
\text { Mean }\end{array}$} & 67.1570 & \\
\hline & & 72.0195 & \\
\hline & 5\% Trimmed Mean & 69.4314 & \\
\hline & Median & 69.0000 & \\
\hline & Variance & 48.553 & \\
\hline & Std. Deviation & 6.96797 & \\
\hline & Minimum & 60.00 & \\
\hline & Maximum & 82.00 & \\
\hline & Range & 22.00 & \\
\hline & Interquartile Range & 12.00 & \\
\hline & Skewness & .050 & .403 \\
\hline & Kurtosis & -1.186 & .78 \\
\hline
\end{tabular}

Sedangkan untuk nilai posttest pembelajaran Scrambel dengan NHT dapat dilihat pada Tabel yaitu: 
Inde pendent Samples Test

\begin{tabular}{|c|c|c|c|c|c|c|c|c|c|}
\hline & \multicolumn{2}{|c|}{$\begin{array}{l}\text { Levene's } \\
\text { Test for } \\
\text { Equality of } \\
\text { Variances }\end{array}$} & \multicolumn{7}{|c|}{ t-test for Equality of Means } \\
\hline & \multirow[b]{2}{*}{$\mathrm{F}$} & \multirow[b]{2}{*}{ Sig. } & \multirow[b]{2}{*}{$\mathrm{t}$} & \multirow[b]{2}{*}{ df } & \multirow{2}{*}{$\begin{array}{c}\text { Sig. } \\
(2- \\
\text { tailed })\end{array}$} & \multirow{2}{*}{$\begin{array}{c}\text { Mean } \\
\text { Differen } \\
\text { ce }\end{array}$} & \multirow{2}{*}{$\begin{array}{c}\text { Std. } \\
\text { Error } \\
\text { Differe } \\
\text { nce }\end{array}$} & \multicolumn{2}{|c|}{$\begin{array}{l}95 \% \text { Confidence } \\
\text { Interval of the } \\
\text { Difference }\end{array}$} \\
\hline & & & & & & & & Lower & Upper \\
\hline $\begin{array}{ll}\mathrm{SC} & \text { Equal } \\
\mathrm{R} / & \text { variances } \\
\mathrm{NH} & \text { assumed }\end{array}$ & $\begin{array}{r}4.07 \\
0\end{array}$ & .048 & -3.825 & 66 & .000 & $5.91176^{-}$ & $\begin{array}{r}1.5457 \\
2\end{array}$ & 8.99789 & -2.82564 \\
\hline $\begin{array}{ll}\mathrm{T} & \text { Equal } \\
\text { variances } \\
\text { not } \\
\text { assumed }\end{array}$ & & & -3.825 & $\begin{array}{r}63.57 \\
3\end{array}$ & .000 & 5.91176 & $\begin{array}{r}1.5457 \\
2\end{array}$ & 9.00009 & -2.82344 \\
\hline
\end{tabular}

Dari tabel independent samples test menunjukkan nilai Sig. (2-tailed) sebesar $0.000<1 / 2 \alpha$ $(0,005)$, artinya terdapat perbedaan hasil belajar antara pembelajaran Scrambel dengan NHT.

\section{KESIMPULAN}

Dari hasil analisis yang telah dilakukan dapat disimpukan bahwa terdapat perbedaan hasil belajar antara model pembelajaran Scrambel dengan model pembelajaran NHT sebesar 0.000 $<1 / 2 \alpha(0,005)$. Sehingga penerapan model pembelajaran Scrambel dan NHT berpengaruh terhadap hasil belajar.

\section{REFERENSI}

Fitriyah N. 2017. Penerapan Metode Pembelajaran Scramble Untuk Meningkatkan Hasil Belajar Siswa Pada Mata Pelajaran Ips Kelas V $S d n$ Ketapangkuning Jombang . 641-649. JPGSD: Unesa Surabaya.

Huda, Miftahul. 2004. Model-Model Pengajaran dan Pembelajaran. Yogyakarta: Pustaka Pelajar.

Isjoni. 2007. Cooperative Learning . Bandung: Al Fabeta.

Maksum, Ali. 2009.

Metodologi Penelitian dalam

Olahraga. Surabaya: Fakultas Ilmu Keolahragaan Universitas Negeri Surabaya.
Muslimin, dkk. 2005. Pembelajaran Kooperatif. Edisi Pertama. Surabaya: Unesa University Press.

Septiaingrum, Resti dkk . 2014. Penerapan Metode Numbered Heads Together (NHT) Disertai Media Tekateki Silang Untuk Meningkatkan Kemampuan Memori dan Prestasi Belajar Kimia Pada Materi Sistem Koloid Kelas Xi Ipa 2 Sma Negeri 2 Karanganyar Tahun Pelajaran 2012/2013. Dalam Jurnal Jurnal Pendidikan Kimia (JPK), Vol. 3 No. 1 Tahun 2014 Program Studi Pendidikan Kimia Universitas Sebelas Maret.

Sya'ban Veni. 2016. Pengaruh Metode Scramble Terhadap Minat Belajar Ips Siswa Kelas V Sd Negeri Rejowinangun 1 Yogyakarta. Skripsi. Universitas Negeri Yogyakarta.

Umar. 2016. Penerapan Model Pembelajaran Kooperatif Taipe STAD untuk Meningkatkan Hasil Belajar Siswa Kelas IXA SMP Negeri 1 Sirenja Pada Materi Uang dan Lembaga Keuangan Bukan Bank. Dalam Jurnal Kreatif Tadulako Online, Vol. 4 No. 4 ISSN 2354-614X. 